\title{
Spatial ecology of blue shark and shortfin mako in southern Peru: local abundance, habitat preferences and implications for conservation
}

\author{
Grant D. Adams ${ }^{1,2,3, *}$, Daniel Flores ${ }^{2}$, Oscar Galindo Flores $^{2}$, Kim Aarestrup ${ }^{4}$, \\ Jon C. Svendsen ${ }^{5,6}$ \\ ${ }^{1}$ Gulf Coast Research Laboratory, University of Southern Mississippi, 703 East Beach Drive, Ocean Springs, MS 39564, USA \\ ${ }^{2}$ Laboratorio Costero de Pisco, Instituto del Mar del Perú IMARPE, Av. Los Libertadores A-12, Urb. El Golf, Paracas, Ica, Peru \\ ${ }^{3}$ Peace Corps Peru, 132 Vía Láctea, Surco, Peru \\ ${ }^{4}$ National Institute of Aquatic Resources, Technical University of Denmark, Vejlsøvej 39, 8600 Silkeborg, Denmark \\ ${ }^{5}$ Interdisciplinary Centre of Marine and Environmental Research, University of Porto, 289 Rua dos Bragas, Porto 4050-123, Portugal \\ ${ }^{6}$ Section for Ecosystem based Marine Management, National Institute of Aquatic Resources (DTU-Aqua), \\ Technical University of Denmark, Jægersborg Allé 1, 2920 Charlottenlund, Denmark
}

\begin{abstract}
While global declines of pelagic shark populations have been recognized for several years, conservation efforts remain hampered by a poor understanding of their spatial distribution and ecology. Two species of conservation concern are the blue shark Prionace glauca and the shortfin mako shark Isurus oxyrinchus. To improve management of these species, this study examined their local abundance patterns, habitat preferences, and distribution in the Southeast Pacific. Catch per unit effort (CPUE) data from an artisanal fishery in Peru were used to identify geographic hot spots and model abundance estimates as a function of environmental variables, including the El Niño Southern Oscillation (ENSO). A 10 yr data series revealed declining annual landings since 2012, despite no changes in management structures. Significant aggregations of both species were found in southwestern Peruvian waters $\left(74-76^{\circ} \mathrm{W}, 17-19^{\circ} \mathrm{S}\right)$, with both speciesspecific hot spots targeted by major fishing efforts. P. glauca CPUE increased during La Niña conditions (i.e. low water temperature anomaly), and CPUE of both species declined when water depths exceeded $1000 \mathrm{~m}$. Correlations with lunar illumination and chlorophyll a were revealed in P. glauca and I. oxyrinchus, respectively. Modeling explained 57 to $61 \%$ of the deviance, indicating that other factors not included in the present study might account for unexplained variance in CPUE (e.g. thermocline depth, location of marine fronts, dissolved oxygen, and gear characteristics). Given the importance of the examined area to shark fisheries and the exploitation of multiple species of conservation concern, the information presented here can be used to inform management strategies designed to limit the depletion of pelagic sharks.
\end{abstract}

KEY WORDS: Artisanal fisheries - Blue shark - Catch per unit effort - Conservation - Spatial ecology $\cdot$ Generalized additive mixed model $\cdot$ Shortfin mako $\cdot$ Habitat preferences

\section{INTRODUCTION}

Recent studies have expressed concerns over the depletion of global pelagic shark populations (Dulvy et al. 2008, Worm et al. 2013, Queiroz et al. 2016) and

${ }^{*}$ Corresponding author: grantadams60091@gmail.com the associated effects on ecosystem functioning (Myers et al. 2007). Declines in pelagic shark populations have been documented in many areas, including the South Atlantic (Barreto et al. 2016), Gulf of Mexico (Baum \& Myers 2004, Hayes et al. 2009), 
Western Pacific (Robbins et al. 2006, Clarke et al. 2013), and the Mediterranean Sea (Ferretti et al. 2008). In the last century, growth in Asian shark fin markets (Dent \& Clarke 2015) and rising global fishing demands have led to increased capture of pelagic sharks either as by-catch or by directed effort (Davidson et al. 2016). Research by Davidson et al. (2016) found that recent declines in the global chondrichthyan catches are strongly correlated to increased fishing pressure and weakly correlated to the often insufficient implementation of management regimes, indicating likely population declines. This is especially concerning as the population growth of many species is unable to match fishing mortality due to life-history constraints including low fecundity and late sexual maturity (Stevens et al. 2000, Worm et al. 2013).

Two species of conservation concern, because of declining populations and exposure to high fishing mortality, are the blue shark Prionace glauca and the shortfin mako Isurus oxyrinchus. P. glauca is the most commonly caught species of pelagic shark (Clarke et al. 2006, FAO 2011), mainly as by-catch of pelagic longline fisheries (Campana et al. 2006). Global $I$. oxyrinchus catches originate from both directed longline fleets and by-catch (Dulvy et al. 2008). Both species are globally distributed and highly migratory, making conservation and management an international effort. However, data are often geographically limited or inconsistent, adding high levels of uncertainty to assessments (Rice et al. 2014). In addition, both species are moderately productive (Dulvy et al. 2008), limiting recovery to high fishing pressure. P. glauca and I. oxyrinchus are therefore classified by the IUCN as Near Threatened and Vulnerable, respectively (Cailliet et al. 2009, Stevens 2009).

In the Southeast Pacific, shark fisheries are poorly monitored and regulated, because fisheries management agencies with limited resources tend to focus on the dominant fisheries of small pelagics and ignore the growing shark catches (Velez-Zuazo et al. 2015). This problem is exacerbated by the fact that most shark populations in the Southeast Pacific are targeted by artisanal fisheries (Bustamante et al. 2014, Gonzalez-Pestana et al. 2014), whose open access can lead to overexploitation and whose local management agencies often lack the capacity to undertake effective fishery assessments (Salas et al. 2007). However, despite the relatively small size of fishing vessels, artisanal fisheries can have large ecological impacts through destructive fishing techniques and large fleet size and activity (Alfaro-Shigueto et al. 2010, Shester \& Micheli 2011).
Peru is the top shark-fishing nation in the Southeast Pacific (Fischer et al. 2012). P. glauca and I. oxyrinchus are the most caught shark species in Peru (Gonzalez-Pestana et al. 2014), with artisanal longline fisheries being the principal harvesters (Gilman et al. 2007). Artisanal vessels are defined in Peru as boats with a maximum of $32.6 \mathrm{~m}^{3}$ gross registered tonnage (GRT), up to $15 \mathrm{~m}$ in length, and operating predominantly using manual labor (AlfaroShigueto et al. 2010). The longline artisanal fisheries have 2 distinct seasons: one for dolphinfish Coryphaena hippurus between December and February where shark catches, while retained, are mostly incidental; the second season is the directed shark fishery, which is mainly active between March and November (Doherty et al. 2014). The shark fishery principally targets $P$. glauca and $I$. oxyrinchus (AlfaroShigueto et al. 2010). Currently, there are no regulations on the finning of sharks, and there are no catch quotas in Peru. Although there is a minimum size limit for both shark species (160 and $170 \mathrm{~cm}$ total length for P. glauca and I. oxyrinchus, respectively), this is rarely enforced (Gilman et al. 2007, Fischer et al. 2012, Doherty et al. 2014). Concerns regarding the expansion of the longline fishery in Peru (>350\% between 1995 and 2005; AlfaroShigueto et al. 2010), rising exports of shark products (Gonzalez-Pestana et al. 2014), and largely absent management warrant further study of these species to help address the status of shark fisheries in this region.

Understanding how and why animals are spatially and temporally distributed is a fundamental component of ecology and is essential for effective conservation and management (Arendt et al. 2012, Kessel et al. 2014, Stehfest et al. 2014, Afonso \& Hazin 2015), partly because spatial ecology can be used to predict vulnerability to marine fisheries. For example, simple descriptors of habitat use can predict the probability of marine species being threatened as defined by the IUCN (Dulvy et al. 2014). Likewise, predictable geographic distributions and aggregations of sharks signal a high potential for overexploitation (Kessel et al. 2014), so distribution knowledge is crucial for the management of protected shark species, particularly if these are perceived as a nuisance or economic opportunity for other fisheries (Gilman et al. 2007). Understanding the biotic and abiotic factors driving shark abundance patterns is important in the context of environmental variation and future climatic scenarios (Kessel et al. 2014) and may help identify the mechanistic bases of species declines, because marine conditions (e.g. primary production and tempera- 
ture) affect pelagic resources (Bigelow et al. 1999, Su et al. 2011). For example, interannual climate variation in the form of the El Niño Southern Oscillation (ENSO) has led to boom and bust fisheries in the Southeast Pacific because of poor knowledge of species' responses to ENSO and a lack of management (Wolff et al. 2007). ENSO greatly alters oceanographic conditions every 2 to $7 \mathrm{yr}$, which affects the status of pelagic fisheries (Ñiquen \& Bouchon 2004, $\mathrm{Su}$ et al. 2011, Quiñones et al. 2015). However, the relationship between ENSO and the local abundance of pelagic shark species remains poorly understood, hampering conservation efforts.

Understanding the distribution and ecology of sharks in Peru, and the effects of climate variation and fishing, can lead to a more accurate index of abundance which can increase the accuracy of future conservation and assessment efforts (Abascal et al. 2011, Doherty et al. 2014, Gonzalez-Pestana et al. 2014). To that end, we modeled P. glauca and I. oxyrinchus catch rates using a $10 \mathrm{yr}$ data set from the small-scale longline fisheries in southern Peru. Using spatial-temporal and environmental variables, we aimed to (1) test the effects of ENSO on P. glauca and I. oxyrinchus; (2) investigate the ecology of these spe- cies in Peruvian waters; (3) report on the spatial distribution of the shark fishery; and (4) examine the temporal development in annual landings.

\section{MATERIALS AND METHODS}

\section{Catch data}

Catch data for Prionace glauca and Isurus oxyrinchus captured by the artisanal longline fleet in the waters of southern Peru (i.e. Arequipa, Moquegua and Tacna Regions) between 2005 and September 2014 were provided by the Instituto del Mar del Perú (IMARPE; Fig. 1). The area covers the principal landing port (by biomass) for sharks in Peru (Ilo, Moquegua) as well as the principal P. glauca and $I$. oxyrinchus fishing grounds (Gonzalez-Pestana et al. 2014).

For each trip, port observers recorded catch per species (kg), vessel GRT, date of landing, and fishing area (Estrella et al. 1998, 1999). While gear and bait are not recorded by IMARPE observers for each fishing trip, on-board observers and port surveys have reported that artisanal longline shark fisheries typi-

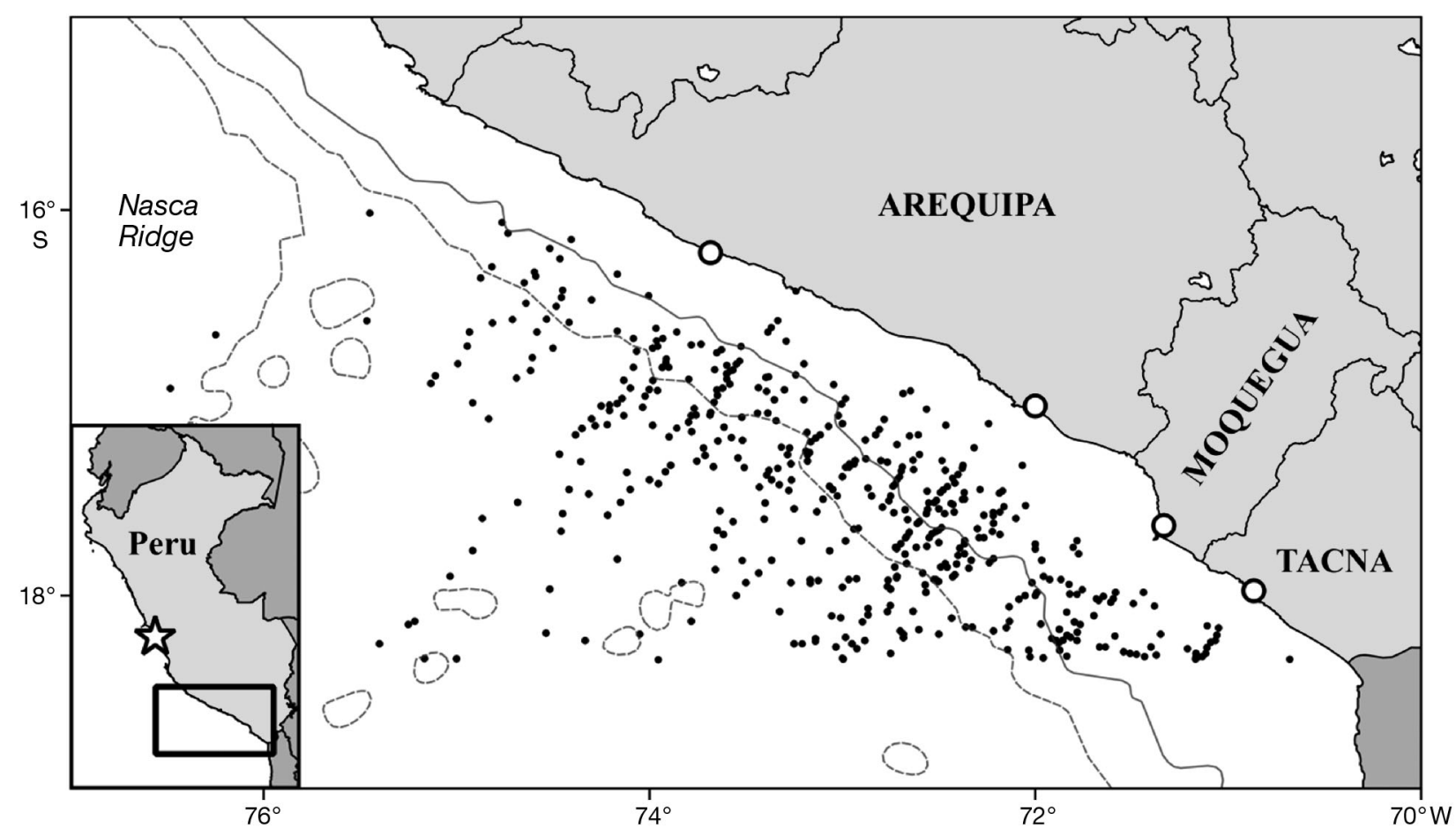

Fig. 1. Fishing locations of blue shark Prionace glauca and shortfin mako shark Isurus oxyrinchus caught by the pelagic artisanal longline fishery in southern Peru from January 2005 to September 2014. Fishing grounds are shown as black dots, landing ports as open circles, and the capital of Peru (Lima) as a star (inset). Depth contours represent the 2000 (solid line) and $4000 \mathrm{~m}$ (dashed lines) isobaths 
cally use large J hooks, nylon multifilament cord branchlines and cable leaders with humboldt squid Dosidicus gigas, flying fish Exocoetus volitans, chub mackerel Scomber japonicus, porcupinefish Diodon hystrix, Peruvian Pacific sardine Sardinops sagax sagax and small cetacean meat as bait (AlfaroShigueto et al. 2010, Doherty et al. 2014). During the dolphinfish season, vessels deploy $7.4 \pm 1.6$ (mean \pm SD) sets per trip with $676.6 \pm 64.6$ hooks per set and during the shark season vessels deploy $7.1 \pm 0.9$ sets per trip with $705.1 \pm 89.8$ hooks per set (Doherty et al. 2014). Nominal catch per unit effort (CPUE) was calculated as catch $(\mathrm{kg})$ per day, which was estimated by dividing the recorded landings by the number of days at sea for each trip. Due to data quality constraints, the nominal CPUE could not be reported in more standardized units, such as catch per set or catch per 1000 hooks.

\section{Environmental data}

Environmental data included in modeling of CPUE were ENSO anomalies, sea surface temperature $\left(\mathrm{SST}^{\circ}{ }^{\circ} \mathrm{C}\right)$, chlorophyll a ( $\mathrm{chl}$ a) concentration (mg $\mathrm{m}^{-3}$ ), water depth (bathymetry; $\mu$ ), and lunar illumination (\%). Monthly oceanic ENSO climate variation data were obtained from the Multivariate ENSO Index (MEI) provided by NOAA's Earth System Research Laboratory (http://www.esrl.noaa.gov/psd/ enso/mei/). The MEI is calculated using the first principal component of sea-level pressure, zonal and meridional surface wind components, SST, surface air temperature, and total cloudiness fraction of the sky from the tropical Pacific (Niño 3.4 region) normalized for the reference period of 1950 to 1993 (Wolter \& Timlin 2011). Positive MEI values represent El Niño phase-like conditions and negative values represent La Niña phase-like conditions. Monthly blended SST and chlorophyll a data with a $4 \mathrm{~km}^{2}$ resolution were retrieved from the Moderate Resolution Imaging Spectrometer Aqua via the Oceancolor Data Downloader QGIS plugin developed by the Mapping and Geographic Information Centre at the British Antarctic Survey (Ireland \& Connor 2015, QGIS Development Team 2015). Daily lunar illumination data at 12 noon (Peru time zone) were extracted from the 'lunar' package in R (R Core Team 2015, Lazaridis 2014). Lunar illumination is the proportion of the Moon's disk that is illuminated and, therefore, new moons have an illumination of 0.0 , full moons have an illumination of 1.0, and quarter moons are intermediate (0.5). This means that lunar illumination corresponds directly to lunar phase. Bathymetry data were obtained from the General Bathymetric Chart of the Oceans global 30 arc-second grid data set (IOC et al. 2003). While fishing area recorded by IMARPE is reported to be accurate within 1 nautical mile (Estrella Arellano \& Swartzman 2010), locations of each set are not recorded and a single point denoting the fishing area is recorded for each trip. To account for possible vessel movement in relation to the recorded fishing area, SST, chl a, and depth within a $13.9 \mathrm{~km}$ radius from each fishing location were averaged. In addition, given the differences in time coverage between environmental variables and fishing trips, the weighted average of environmental variables was calculated over the duration of each fishing trip.

\section{GAMM modeling}

To examine the relationships of pelagic shark catch rates with spatial-temporal and environmental variables, generalized additive mixed models (GAMMs; Wood 2006) were fit to the CPUE data (Bigelow et al. 1999, Bustamante \& Bennett 2013, Mitchell et al. 2014). Vessel-specific heterogeneity was included as a random effect (random intercept) to remove the assumption of homogeneity of gear and fishing characteristics among vessels and improve standardization of CPUE. To reduce Type I and II errors, GAMMs were constructed using cubic regression splines and fitted using restricted maximum likelihood to maximize stability (Marra \& Wood 2011). In addition, the 'double penalty' shrinkage variable selection procedure was used to reduce uncertainty inherent in stepwise variable selection procedures (Marra \& Wood 2011). Employing log transformed CPUE data for each species to meet the assumption of normality, GAMMs were fitted using a normal distribution and an identity link function to fit the response:

$$
\begin{aligned}
& \log (\mathrm{CPUE}+1) \sim s(\mathrm{MEI})+s(\mathrm{SST})+s(\mathrm{chl} a)+s(\text { lunar } \\
& \text { illumination })+s(\text { depth })+s(\text { month })+ \\
& s(\text { year })+s(\text { latitude })+s(\text { longitude })+s(\mathrm{GRT})+\alpha_{i}
\end{aligned}
$$

where $s$ is the smoothing function applied to each covariate, $\alpha_{i}$ is the vessel-specific random effect, and a constant of 1 was added to CPUE. The effect of month was modeled using cyclic cubic regression splines. Spatial prediction maps of CPUE were created for both species using the modeled effect of latitude and longitude. GAMM analyses were completed using the 'gamm4' package in R 3.2.1 (Wood \& Scheipl 2014, R Core Team 2015), with significance accepted at $\mathrm{p}<0.01$. 


\section{Spatial distribution}

Distributional patterns of pelagic sharks off the southeast coast of Peru were identified using the Optimized Hot Spot Analysis tool (Getis-Ord Gi* statistic) in ArcGIS 10.2.2 (Environmental Systems Research Institute), similar to Love et al. (2015) and Queiroz et al. (2016). CPUE of each species was averaged over $0.25 \times 0.25^{\circ}$ grid cells for analysis by the $\mathrm{Gi}^{*}$ statistic (Robinson \& Graham 2013). The Gi* statistic indicates the level of clustering of CPUE, with positive and negative values noting areas where pelagic sharks are most (hot spots) and least (cold spots) encountered, respectively. A standard distance calculation was used to determine the optimal distance band based on the average distance to the 30 nearest neighbors after removing locational outliers, features more than 3 standard deviations away from their closest non-coincident neighbor. Areas were considered significantly hot (positive $\mathrm{Gi}^{*}$ ) or cold (negative $\mathrm{Gi}^{*}$ ) at $\mathrm{p} \leq 0.05$. Catch data from March to November (i.e. shark season) and December to February (i.e. dolphinfish season) were analyzed separately because fishing techniques and gear characteristics of vessels vary for each distinct fishing season.

\section{RESULTS}

Between January 2005 and September 2014, 4971 fishing trips of the artisanal longline fleet in southern Peru landed $1621.2 \mathrm{t}$ of $P$. glauca and $875.9 \mathrm{t}$ of I. oxyrinchus (Table 1). Landings increased during the beginning of the study period and started declin- ing after 2012 (Fig. 2). Data were excluded from further analyses if departure date was not recorded (i.e. trip duration could not be calculated). Thus, $1253 \mathrm{t}$ of $P$. glauca and $697 \mathrm{t}$ of $I$. oxyrinchus landings from 3025 artisanal longline trips in Peruvian waters were used in GAMMs and hot spot analyses. The majority of catches observed occurred during the shark season, when trip length and CPUE were greater, rather than the dolphinfish season (Table 1).

\section{Effects of environmental and spatial-temporal variables on CPUE}

For Prionace glauca, results of the GAMMs indicated that all input variables except chlorophyll a

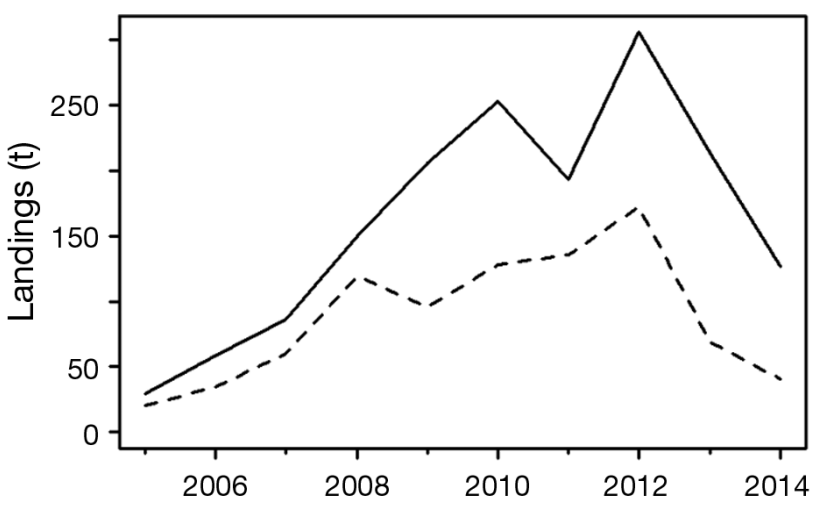

Fig. 2. Yearly landings in metric tonnes (t) of blue shark Prionace glauca (solid line) and shortfin mako shark Isurus oxyrinchus (dashed line) from the artisanal longline fleet in southern Peru, January 2005-September 2014. For both species, landings peaked in 2012, followed by a declining trend

Table 1. Catch and effort data for the study period by fishing season (shark and dolphinfish). Note that summary statistics were calculated only from data with complete landing and departure date information and are included under 'GAMM and hot spot analyses.' Data are displayed as mean \pm SD with ranges in parentheses. GRT: gross registered tonnage; CPUE: catch per unit effort

\begin{tabular}{|c|c|c|c|}
\hline & Shark season (Mar-Nov) & Dolphinfish season (Dec-Feb) & Total \\
\hline \multicolumn{4}{|l|}{ Total } \\
\hline Prionace glauca landed (t) & 1377.3 & 243.9 & 1621.2 \\
\hline Isurus oxyrinchus landed (t) & 707.6 & 168.3 & 875.9 \\
\hline Number of trips & 1711 & 3260 & 4971 \\
\hline \multicolumn{4}{|l|}{ GAMM and hot spot analyses } \\
\hline$P$. glauca landed $(\mathrm{t})$ & 1072.8 & 179.2 & 1253 \\
\hline I. oxyrinchus landed (t) & 566.8 & 130.2 & 697 \\
\hline Number of trips & 1160 & 1865 & 3025 \\
\hline Fishing days & 21938.5 & 18566.7 & 40505.2 \\
\hline GRT & $5.4 \pm 2.1(1.5-16)$ & $6.3 \pm 2.6(2-20)$ & $5.7 \pm 2.4(1.5-20)$ \\
\hline Mean trip length (d) & $12 \pm 6.3(1-31)$ & $7.9 \pm 2.9(1-27)$ & $9.7 \pm 5.1(1-31)$ \\
\hline Mean CPUE $\left(\mathrm{kg} \mathrm{d}^{-1}\right)$ & $63.3 \pm 68.6(0.6-483.9)$ & $12.9 \pm 32.1(0.4-478.5)$ & $35 \pm 57(0.4-483.5)$ \\
\hline
\end{tabular}


were significant predictors of CPUE (Table 2). For Isurus oxyrinchus, 8 of the 10 input variables were significant predictors of CPUE (Table 2). Modelling explained the majority of the deviance for $P$. glauca (adjusted $\mathrm{r}^{2}=0.58$ ) and $I$. oxyrinchus (adjusted $\mathrm{r}^{2}=$ 0.61). Standard model diagnostics suggested that both models fit the data well (Fig. A1 in the Appendix).

The effect of the MEI variable on P. glauca and I. oxyrinchus peaked at -2.0 , dropping as MEI increased, indicating a positive correlation between CPUE and La Niña ENSO phase-like conditions (i.e. cooling events; Fig. 3). MEI values between 0.5 and 1.5 had no effect on P. glauca CPUE. Peak P. glauca CPUE occurred when lunar illumination was 0 and $100 \%$ (Fig. 3a). The influence of SST on P. glauca CPUE peaked between 14.5 and $20^{\circ} \mathrm{C}$, while $20^{\circ} \mathrm{C}$ SST coincided with elevated CPUE in I. oxyrinchus (Fig. 3b). CPUE of I. oxyrinchus was much greater at chl $a$ values approaching $0 \mathrm{mg} \mathrm{m}^{-3}$, then decreased drastically to plateau until $4 \mathrm{mg} \mathrm{m}^{-3}$ (Fig. 3b). The depth covariate demonstrated much higher $P$. glauca and I. oxyrinchus CPUE at $\sim 1000 \mathrm{~m}$ sea depth, decreasing as depth increased. The month predictor

Table 2. Summary of generalized additive mixed models (GAMMs), relating blue shark Prionace glauca and shortfin mako shark Isurus oxyrinchus catch per unit effort $\left(\mathrm{kg} \mathrm{d}^{-1}\right)$ data to spatial-temporal and environmental variables in southern Peru (cutoff for significance set at $\alpha=0.01$ ). Data for the analyses are described in detail in Table 1. MEI: Multivariate ENSO Index; SST: sea surface temperature; GRT: gross registered tonnage; edf: estimated degrees of freedom

\begin{tabular}{|c|c|c|c|}
\hline Predictor & edf & $F$ & $\mathrm{p}$-value \\
\hline \multicolumn{4}{|l|}{ P. glauca } \\
\hline MEI & 3.0 & 8.8 & $\ll 0.0001$ \\
\hline SST & 4.0 & 4.7 & $\ll 0.0001$ \\
\hline Lunar illumination & 2.5 & 2.0 & 0.0038 \\
\hline Depth & 3.3 & 5.6 & $\ll 0.0001$ \\
\hline Month & 7.0 & 98.9 & $\ll 0.0001$ \\
\hline Year & 5.7 & 7.8 & $\ll 0.0001$ \\
\hline GRT & 4.7 & 32.8 & $\ll 0.0001$ \\
\hline Latitude & 4.4 & 10.9 & $\ll 0.0001$ \\
\hline Longitude & 7.1 & 16.0 & $\ll 0.0001$ \\
\hline \multicolumn{4}{|l|}{ I. oxyrinchus } \\
\hline $\mathrm{SST}^{2}$ & 5.1 & 3.8 & 0.002 \\
\hline Chlorophyll a & 6.6 & 6.6 & $\ll 0.0001$ \\
\hline Depth & 4.0 & 17.6 & $\ll 0.0001$ \\
\hline Month & 5.9 & 67.2 & $\ll 0.0001$ \\
\hline Year & 5.1 & 11.0 & $\ll 0.0001$ \\
\hline GRT & 3.0 & 15.9 & $\ll 0.0001$ \\
\hline Latitude & 1.0 & 109.4 & $\ll 0.0001$ \\
\hline Longitude & 1.3 & 44.9 & $\ll 0.0001$ \\
\hline
\end{tabular}

showed that CPUE of P. glauca is highly seasonal, with elevated values from April to October (Fig. 3a). For I. oxyrinchus, peak CPUE was between April and July (Fig. 3b). For both species, the year predictor demonstrated steady declines in CPUE until $2008(P$. glauca) and 2010 (I. oxyrinchus), followed by increasing and plateauing trends for P. glauca and I. oxyrinchus towards the end of the study period, respectively (Fig. 3). CPUE also increased for both species with increasing GRT, at least up to 10 to 15 GRT (Fig. 3).

CPUE spatial predictions (based on GAMMs) indicated much higher CPUE of $P$. glauca in the southwest and north of the study area (Fig. 4a). In contrast, I. oxyrinchus CPUE was greatest in the southwest corner of the study area, declining steeply north and eastwards (Fig. 4b). However, the extent of spatial predictions for $I$. oxyrinchus CPUE was less than for P. glauca, given the lack of captures beyond $\sim 75.5^{\circ} \mathrm{W}$.

\section{CPUE spatial distribution and hot spots}

Hot spot analyses revealed 3 distinct, and highly overlapping (i.e. sympatric), clusters of greater probability of encountering $P$. glauca and $I$. oxyrinchus (CPUE) by artisanal longline fisheries during both the dolphinfish season (December to February) and the shark fishing season (March to November; Fig. 5). For P. glauca, 16.5 and $5.4 \%$ of the area examined in which sharks were present was considered a hot spot during the shark and dolphinfish season, respectively (i.e. 15 of 91 and 5 of 93 grid cells, respectively). Hot spots of P. glauca CPUE were located in the southwest corner of the study area (Fig. 5). For I. oxyrinchus, 10 and $8 \%$ of the area in which sharks were captured was considered a hot spot during the shark and dolphinfish season, respectively (i.e. 8 of 80 and 6 of 75 grid cells, respectively). The $I$. oxyrinchus hot spots were located in the southwest and southeast corner of the study area (Fig. 5). In addition, cold spots for each species and season were identified along the coast (Fig. 5, blue region). Overall, 775.1 and $34.7 \mathrm{t}$ of P. glauca and 489 and $82.4 \mathrm{t}$ of $I$. oxyrinchus were caught from the identified hot spots during the shark and dolphinfish seasons, respectively, indicating the importance of these areas to pelagic sharks in the region. However, only 3.5 and $2.2 \mathrm{t}$ of I. oxyrinchus were captured during the shark and dolphinfish seasons, respectively, from the hot spot in the southeast of the study area. 

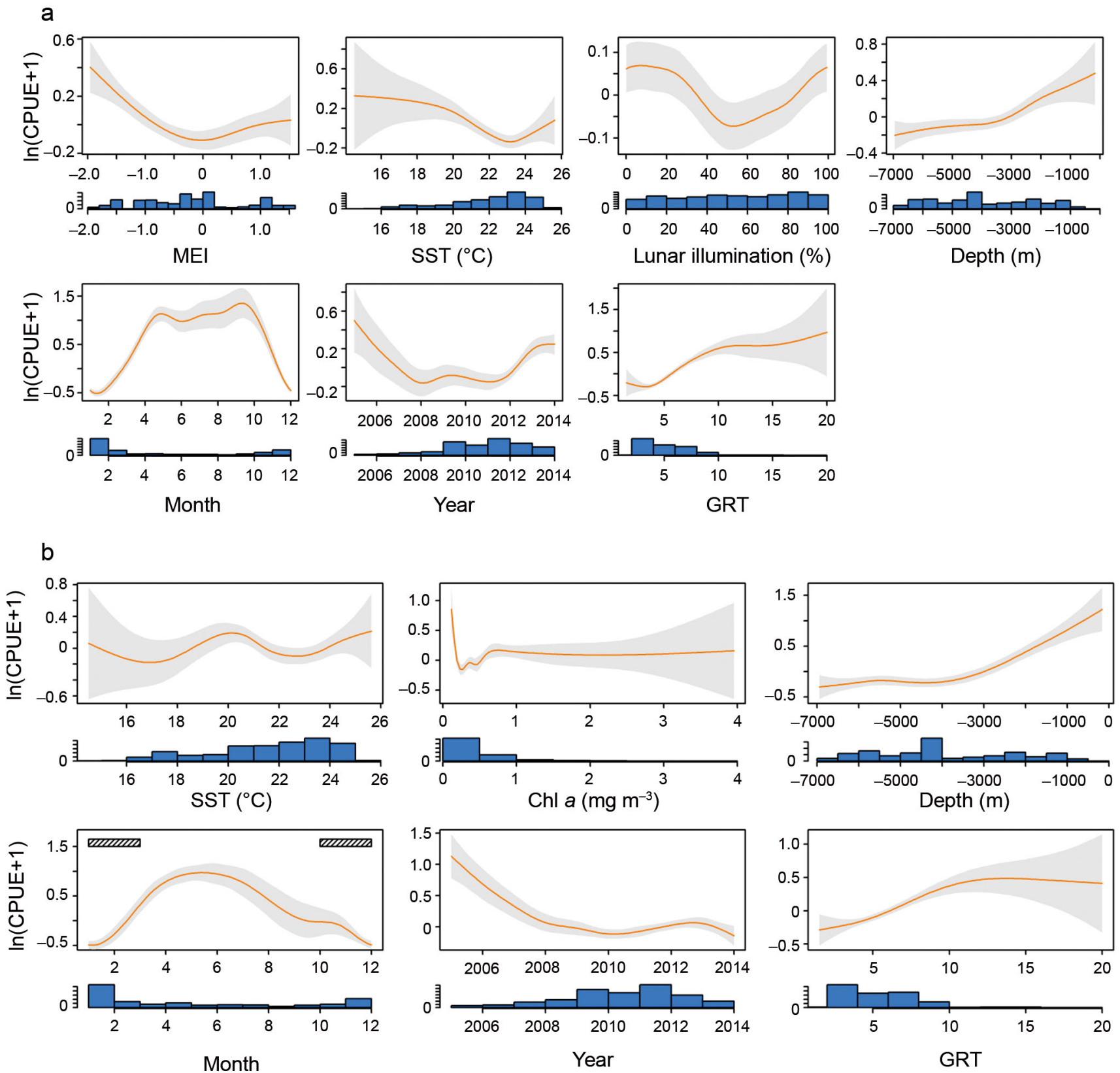

Fig. 3. GAMM analyzed and fitted partial response curves showing the effects of spatial-temporal and environmental variables on catch per unit effort (CPUE; $\mathrm{kg} \mathrm{d}^{-1}$ ) for artisanal longline fisheries in southern Peru, January 2005-September 2014 (see Table 2) of (a) blue shark Prionace glauca and (b) shortfin mako shark Isurus oxyrinchus (bars in 'Month' panel mark the pupping season; Bustamante \& Bennett 2013). Negative Multivariate ENSO Index (MEI) values correspond to La Niña phaselike conditions involving cold water anomalies. Grey shading indicates the $95 \%$ confidence interval. Note that $y$-axes differ between panels, with zeros corresponding to the centered values. Fishing effort (number of trips) is indicated in the lower panels with blue vertical bars. CPUE: catch per unit effort; SST: sea surface temperature; GRT: gross registered tonnage

\section{DISCUSSION}

This study provides the first assessment of the distribution and spatial ecology of Prionace glauca and Isurus oxyrinchus in the Southeast Pacific using data from the artisanal longline fishery in the southern
Peru. GAMMs presented here explain a large proportion $(>57 \%)$ of the deviance of shark catch rates using predictors that are known to influence the spatial and temporal distribution, and local abundance of sharks (Bigelow et al. 1999, Carvalho et al. 2011, Bustamante \& Bennett 2013), thus providing a mean- 

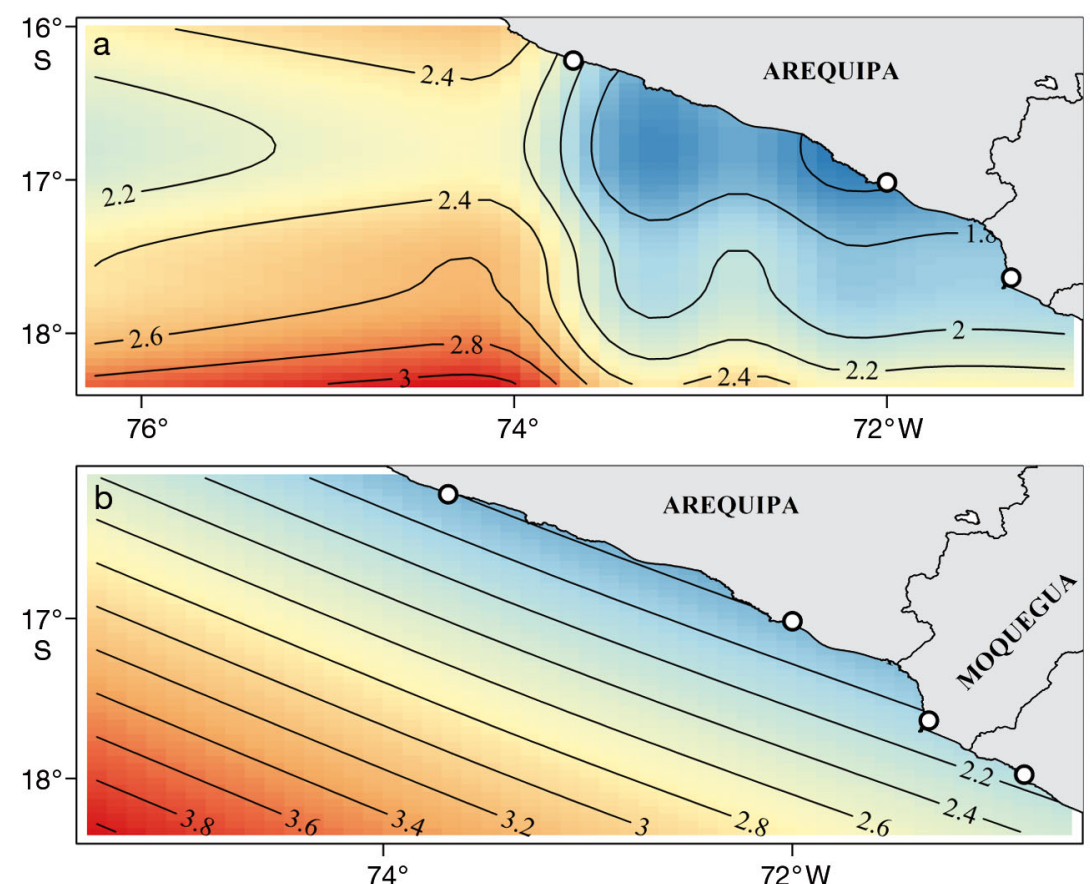

Fig. 4. Spatial distribution of GAMM-predicted natural log-transformed catch per unit effort (CPUE; $\mathrm{kg} \mathrm{d}^{-1}$ ) of (a) blue shark Prionace glauca and (b) shortfin mako shark Isurus oxyrinchus caught by the artisanal longline fleet in southern Peru, January 2005-September 2014. Colour scale indicated by the numbers next to the isopleths

ingful interpretation of the ecological processes that may affect these species in the Southeast Pacific. Given the importance of artisanal fisheries in the region (Alfaro-Shigueto et al. 2010, Estrella Arellano \& Swartzman 2010) and related conservation concerns, the present study addresses pertinent gaps in our understanding of the distribution and ecology of pelagic sharks in the Southeast Pacific.

\section{Impacts of ENSO}

The study assessed for the first time the non-linear effects of ENSO on P. glauca and I. oxyrinchus in southern Peru. Previously, Gonzalez-Pestana et al. (2014) found a positive correlation between ENSO and P. glauca and I. oxyrinchus monthly landings by the artisanal longline fishery in Peru using linear regression. The use of CPUE and GAMMs suggests that these models more accurately reveal possible non-linear effects of ENSO on shark fisheries in southern Peru. In contrast to Gonzalez-Pestana et al. (2014), the present study found that P. glauca is impacted by strong La Niña events (i.e. when MEI was negative) and ENSO has no significant impact on I. oxyrinchus. Further differences between the results of the present study and those of Gonzalez-Pestana et al. (2014) may be due to latitude, interdecadal climate regime (i.e. El Viejo vs. La Vieja), or area-specific effects of ENSO, as Gonzalez-Pestana et al. (2014) analyzed data from the entire country covering multiple interdecadal climate regimes. The time period of the present study lacked strong El Niño events and represents the La Vieja regime, marked by cooler waters and the dominance of anchovies over sardines (Chavez et al. 2003). Thus, further study is warranted to examine the impacts of El Viejo and strong positive ENSO anomalies. Given the large horizontal distributions of the examined species beyond the study area and exclusion of a temporal lag to account for possible population growth, ENSO most likely alters the local abundance of $P$. glauca in southern Peru. ENSO anomalies influence the distribution of large pelagic species such as blue marlin Makaira nigricans by altering the location of favorable habitat (i.e. temperature and primary production) (Su et al. 2011). In addition, alterations in the horizontal distribution and abundance of prey species due to ENSO (Ñiquen \& Bouchon 2004, Adams \& Flores 2016) could act as a driver of local shark abundances, as documented for other upper trophic level species (Cury et al. 2000).

\section{Ecology}

Environmental predictors such as SST and chl a play significant roles in the local abundance patterns of pelagic sharks due to optimal thermal ranges and food availability (Bigelow et al. 1999, Carvalho et al. 2011, Mitchell et al. 2014). As demonstrated by our results, CPUE was greatest at 14.5 to $20^{\circ} \mathrm{C}$ for $P$. glauca and $20^{\circ} \mathrm{C}$ for $I$. oxyrinchus. These results are similar to studies in the North Pacific (Walsh \& Kleiber 2001) and South and North Atlantic (Carvalho et al. 2011, Vandeperre et al. 2014) which reported that $P$. glauca CPUE was greatest at temperatures ranging from 16 to $21^{\circ} \mathrm{C}$. Furthermore, tagging of I. oxyrinchus by Abascal et al. (2011) in Chilean waters found that relative time spent at a certain temperature peaked between 20 and $22^{\circ} \mathrm{C}$. Similar to work in the northern Pacific (Walsh \& Kleiber 2001), 

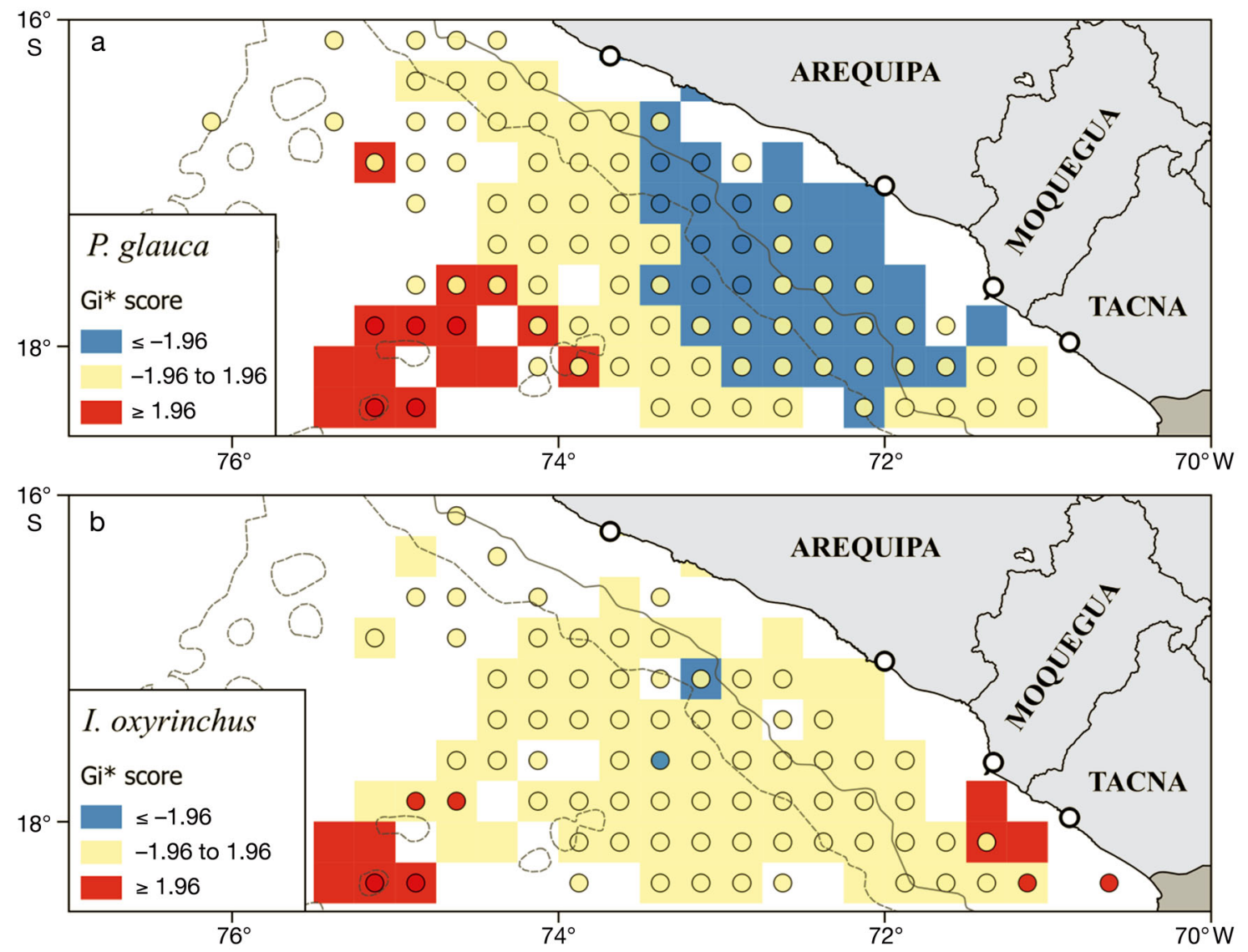

Fig. 5. Long-term distributional patterns in (a) blue shark Prionace glauca and (b) shortfin mako shark Isurus oxyrinchus catch per unit effort (CPUE; $\mathrm{kg} \mathrm{d}^{-1}$ ). Spatial patterns for each species were computed using the Getis-Ord hot spot analysis Gi* statistic (z-score), with positive and negative $\mathrm{Gi}^{*}$ statistics indicating hot (red) and cold (blue) areas, respectively, for the probability of encountering each species in southern Peru. Circles represent CPUE hot spots during the dolphinfish season (December to February) and squares represent CPUE hot spots from the shark fishing season (March to November). Areas were considered significantly hot or cold at $p \leq 0.05\left(\left|\mathrm{Gi}^{*}\right| \geq 1.96\right)$. Open circles along the shoreline indicate ports significant to the pelagic artisanal fishery. Depth contours represent the 2000 (solid line) and $4000 \mathrm{~m}$ (dashed lines) isobaths

we noticed an increase in P. glauca CPUE at the highest temperatures observed, although the underpinning mechanism is unknown.

Primary production may act as a proxy of prey availability because many of the prey species of pelagic sharks are reliant on primary production (Chassot et al. 2010). Correspondingly, chl a plays a significant role in abundance patterns of pelagic sharks (Carvalho et al. 2011). In eastern boundary upwelling ecosystems (EBUEs) migratory sharks forage primarily on the edge of highly productive upwelling environments (Chavez \& Messié 2009). Thus, as expected, I. oxyrinchus catch rates were highest when primary production was lowest.

Lunar illumination and lunar phase affect fish species in multiple manners, including visual detection of prey and predator camouflage, and may change fish distribution, thermal exposure, and activity pat- terns (Metcalfe et al. 1997, Hanson et al. 2008, Aarestrup et al. 2009, Afonso \& Hazin 2015, Papastamatiou et al. 2015, Schabetsberger et al. 2015). Shark prey species may modify vertical distributions according to the lunar phase (Schabetsberger et al. 2013, 2015), suggesting that lunar phase (and illumination) influences the distribution of foraging sharks. Because lunar effects on pelagic sharks are unknown in the Southeast Pacific, the effects of lunar illumination were tested on P. glauca and $I$. oxyrinchus CPUE. Despite the fact that the 2 species are sympatric and may have been foraging on similar prey species, results revealed contrasting findings, with no lunar effects on $I$. oxyrinchus, whereas $P$. glauca CPUE varied with lunar illumination. Previous studies of lunar effects on P. glauca and I. oxyrinchus have not reported consistent findings. In the northern Atlantic Ocean, Vandeperre et al. (2014) found that 
P. glauca CPUE peaked at intermediate moons, partly supported by Lowry et al. (2007) who reported that CPUE of P. glauca and I. oxyrinchus peaked during the waxing crescent in the western South Pacific. Poisson et al. (2010) reported no lunar effects on CPUE of $P$. glauca and Isurus spp. in the western Indian Ocean. In support of the present study, Bigelow et al. (1999) found that P. glauca CPUE tended to peak during new moon and full moon in the North Pacific. The varying findings indicate that the mechanistic basis for lunar effects on shark CPUE may comprise a complex array of factors, perhaps including the behavior of various prey species. However, the effects of mixed-layer depth, thermocline, locations of marine fronts, oxygen concentration, and other oceanographic factors not included in the present study may contribute to unexplained deviance in the present modeling approach.

\section{Spatial distribution}

Both I. oxyrinchus and P. glauca are primarily pelagic species with global distributions (Compagno 2001). Many shark species, however, aggregate for foraging or reproduction purposes, and hot spots in abundance and aggregations of pelagic sharks have been found in the Northeast Pacific (Williams et al. 2010) and the North Atlantic (Vandeperre et al. 2014, Queiroz et al. 2016). The present study adds to these findings by describing hot spots in the Southeast Pacific. Hypotheses for the importance of shark aggregation include reproductive and feeding opportunities. Comparable with other species (Williams et al. 2010), the tendency of many pelagic sharks to aggregate makes them especially vulnerable to overexploitation (Litvinov 2006, Dulvy et al. 2008). In the present study, the greatest abundance of $P$. glauca and $I$. oxyrinchus was found far offshore $(>150 \mathrm{~km}$ from the shore) in the southwest corner of the study area where there was a statistically significant clustering of elevated CPUE (hot spots), corroborating high catch rates in the study area identified by onboard observers (Doherty et al. 2014). The importance of the hot spots in the southwest is indicated by the fact that a greater percentage of all shark captures originated from these hot spot areas. However, hot spots for $I$. oxyrinchus in the southeast of the study area were primarily driven by 2 fishing trips with relatively high CPUE and therefore these areas are likely not as significant to local shark populations and the artisanal fishery. GAMMs indicate another concentration of elevated CPUE for P. glauca further north in the study area. While fishing effort is minimal in this region, aggregations of $P$. glauca have previously been found associated with the Nasca Ridge (Litvinov 2006; Fig. 1). Given that GAMMs standardize CPUE to vessel size (GRT), temporal, and environmental predictors, spatial distribution of CPUE as predicted by GAMMs may more accurately portray the true distribution of the examined species than hot spot analysis. In addition, both methods indicate that the study area does not completely cover the population centers of these sharks, and international effort is required to fully elucidate the distribution of both species.

\section{Temporal patterns}

As described previously, the shark fishery in Peru is seasonal (Doherty et al. 2014). Bait species described by Doherty et al. (2014) follow seasonal abundance patterns (Estrella Arellano \& Swartzman 2010) that correspond to peak shark CPUE. Thus, shark abundance patterns in the study area may follow seasonal prey abundance patterns to take advantage of greater prey availability. However, because gear characteristics and fishing techniques change depending on the season (Alfaro-Shigueto et al. 2010), seasonal trends in CPUE in our GAMMs may partly reflect gear-specific selectivity and fleet direction. Therefore, fishery-independent research is needed to examine seasonal migration and abundance patterns.

Corroborating the increasing landings up until 2010 (Gonzalez-Pestana et al. 2014) and contrary to CPUE reported by previous studies (Doherty et al. 2014), the present study found a decline in the CPUE of P. glauca and I. oxyrinchus from the beginning of the study period to around 2009. In more recent years, annual landings of $P$. glauca have declined although CPUE has increased. While assessments of $P$. glauca and I. oxyrinchus are absent for the Southeast Pacific, assessments from the North Pacific found declining trends of $P$. glauca abundance in the 2000s when using CPUE data from the Secretariat of the Pacific Community's observer program and observers on longline vessels based in Hawaii (Rice et al. 2014). However, when CPUE series from the Japanese longline fleet were used, abundance estimates were more optimistic. In the Southwest Pacific, CPUE for P. glauca and I. oxyrinchus generally increased between 2005 and 2013 (Francis et al. 2014). Differences between studies are likely due to geographic differences in local population dynamics, fishing pressure and mortality, temporal span of the CPUE series, and CPUE standardization techniques. 


\section{CONCLUSION}

Due to biological constraints related to life history, combined with increasing fishing pressures, P. glauca and $I$. oxyrinchus have been listed as species of conservation concern by the IUCN Red List. Despite these concerns, the availability of fishery and biological data continues to be limited, especially in the Southeast Pacific, thus restricting conservation possibilities for these species. In particular, while Estrella Arellano \& Swartzman (2010) note that the accuracy of location of fishing site recorded by IMARPE is to within 1 nautical mile, the present study is limited by the lack of information on the start and end locations of sets. Soak time, bait, and gear for each trip, which can affect catch rates of pelagic sharks, are not recorded by port observers (Gallagher et al. 2014). Furthermore, due to a lack of available information on the number of sets per trip and hooks per set, the definition of CPUE used here may be biased. The present study addressed these issues by averaging environmental data over large grid space to account for possible vessel movement, using the most detailed definition of CPUE possible given the data available from the fishery, and using a mixed model structure to account for inter-vessel heterogeneity in gear and fishing techniques. The similarity between these results and previous studies (Walsh \& Kleiber 2001, Chavez \& Messié 2009, Abascal et al. 2011, Doherty et al. 2014, Vandeperre et al. 2014) in terms of greater CPUE on the southern border of the study area, seasonality of the fishery, associations between CPUE at SST, and greater CPUE of $I$. oxyrinchus at low chlorophyll levels adds credibility to the findings, despite the apparent limitations. However, more extensive data from fishery (e.g. number of sets per trip, number of hooks per set, and negative catch data) and fishery-independent studies are needed to better evaluate and understand the status, ecology, and distribution of P. glauca and I. oxyrinchus in this region. For example, effort by the artisanal longline fleet has been recorded in Chilean waters (Doherty et al. 2014); however, catch data from these areas are not accurately georeferenced. Therefore, further effort to improve portside data collection and fisheries-independent surveys are necessary to examine the ecology and distribution of pelagic sharks to the south of the present study.

Acknowledgments. We thank the staff at IMARPE Ilo and Camaná for their assistance with the acquisition of catch data and the staff of IMARPE Pisco for their valuable support. This research was supported by a grant (SFRH/BPD/ 89473/2012) from the Foundation for Science and Technology (FCT) in Portugal to J.C.S.

\section{LITERATURE CITED}

Aarestrup K, Okland F, Hansen MM, Righton D and others (2009) Oceanic spawning migration of the European eel (Anguilla anguilla). Science 325:1660

Abascal FJ, Quintans M, Ramos-Cartelle A, Mejuto J (2011) Movements and environmental preferences of the shortfin mako, Isurus oxyrinchus, in the southeastern Pacific Ocean. Mar Biol 158:1175-1184

Adams GD, Flores D (2016) Influencia de El Niño Oscilación del Sur en la disponibilidad y abundancia de recursos hidrobiológicos de la pesca artesanal en Ica, Perú. Rev Biol Mar Oceanogr 51:265-272

Afonso AS, Hazin FHV (2015) Vertical movement patterns and ontogenetic niche expansion in the tiger shark, Galeocerdo cuvier. PLoS ONE 10:e0116720

Alfaro-Shigueto J, Mangel JC, Pajuelo M, Dutton PH, Seminoff JA, Godley BJ (2010) Where small can have a large impact: structure and characterization of small-scale fisheries in Peru. Fish Res 106:8-17

Arendt MD, Boynton J, Schwenter JA, Byrd JI and others (2012) Spatial clustering of loggerhead sea turtles in coastal waters of the NW Atlantic Ocean: implications for management surveys. Endang Species Res 18:219-231

Barreto R, Ferretti F, Mills J, Amorim A, Andrade H, Worm B, Lessa R (2016) Trends in the exploitation of South Atlantic shark populations. Conserv Biol 30:792-804

Baum JK, Myers RA (2004) Shifting baselines and the decline of pelagic sharks in the Gulf of Mexico. Ecol Lett 7:135-145

Bigelow KA, Boggs CH, He X (1999) Environmental effects on swordfish and blue shark catch rates in the US North Pacific longline fishery. Fish Oceanogr 8:178-198

Bustamante C, Bennett MB (2013) Insights into the reproductive biology and fisheries of two commercially exploited species, shortfin mako (Isurus oxyrinchus) and blue shark (Prionace glauca), in the south-east Pacific Ocean. Fish Res 143:174-183

Bustamante C, Vargas-Caro C, Bennett MB (2014) Not all fish are equal: functional biodiversity of cartilaginous fishes (Elasmobranchii and Holocephali) in Chile. J Fish Biol 85:1617-1633

Cailliet GM, Cavanagh RD, Kulka DW, Stevens JD and others (2009) Isurus oxyrinchus. The IUCN Red List of Threatened Species 2009:e.T39341A10207466. http://dx. doi.org/10.2305/IUCN.UK.2009-2.RLTS.T39341A10207466. en (accessed 10 Aug 2015)

> Campana SE, Marks L, Joyce W, Kohler NE (2006) Effects of recreational and commercial fishing on blue sharks (Prionace glauca) in Atlantic Canada, with inferences on the North Atlantic population. Can J Fish Aquat Sci 63: 670-682

> Carvalho FC, Murie DJ, Hazin FHV, Hazin HG, LeiteMourato B, Burgess GH (2011) Spatial predictions of blue shark (Prionace glauca) catch rate and catch probability of juveniles in the Southwest Atlantic. ICES J Mar Sci 68: 890-900

Chassot E, Bonhommeau S, Dulvy NK, Mélin F, Watson R, Gascuel D, Le Pape O (2010) Global marine primary production constrains fisheries catches. Ecol Lett 13:495-505 > Chavez FP, Messié M (2009) A comparison of eastern boundary upwelling ecosystems. Prog Oceanogr 83:80-96

> Chavez FP, Ryan J, Lluch-Cota SE, Niquen CM (2003) From anchovies to sardines and back: multidecadal change in the Pacific Ocean. Science 299:217-221 
Clarke SC, McAllister MK, Milner-Gulland EJ, Kirkwood GP and others (2006) Global estimates of shark catches using trade records from commercial markets. Ecol Lett 9:1115-1126

> Clarke SC, Harley SJ, Hoyle SD, Rice JS (2013) Population trends in Pacific oceanic sharks and the utility of regulations on shark finning. Conserv Biol 27:197-209

Compagno LJV (2001) Sharks of the world. An annotated and illustrated catalogue of shark species known to date. FAO, Rome

Cury P, Bakun A, Crawford R, Jarre A, Quiñones R, Shannon L, Verheye H (2000) Small pelagics in upwelling systems: patterns of interaction and structural changes in 'wasp-waist' ecosystems. ICES J Mar Sci 57:603-618

> Davidson LNK, Krawchuk MA, Dulvy NK (2016) Why have global shark and ray landings declined: improved management or overfishing? Fish Fish 17:438-458

Dent F, Clarke S (2015) State of the global market for shark products. FAO Fisheries and Aquaculture Technical Paper No. 590. FAO, Rome

> Doherty PD, Alfaro-Shigueto J, Hodgson DJ, Mangel JC, Witt MJ, Godley BJ (2014) Big catch, little sharks: insight into Peruvian small-scale longline fisheries. Ecol Evol 4: 2375-2383

Dulvy NK, Baum JK, Clarke S, Compagno LJV and others (2008) You can swim but you can't hide: the global status and conservation of oceanic pelagic sharks and rays. Aquat Conserv 18:459-482

Dulvy NK, Fowler SL, Musick JA, Cavanagh RD and others (2014) Extinction risk and conservation of the world's sharks and rays. eLife 3:e00590

Estrella C, Guevara-Carrasco R, Palacios J (1998) Informe estadístico de los recursos hidrobiológicos de la pesca artesanal por especies, artes, caletas y meses durante el primer semestre de 1998. Instituto del Mar del Perú, Callao

Estrella C, Guevara-Carrasco R, Medina A, Palacios J, Avila YW (1999) Informe estadístico de los recursos hidrobiológicos de la pesca artesanal por especies, artes, caletas y meses durante el segundo semestre de 1998. Instituto del Mar del Perú, Callao

Estrella Arellano C, Swartzman G (2010) The Peruvian artisanal fishery: changes in patterns and distribution over time. Fish Res 101:133-145

FAO (2011) Review of the state of world marine fishery resources. FAO, Rome

Ferretti F, Myers RA, Serena F, Lotze HK (2008) Loss of large predatory sharks from the Mediterranean Sea. Conserv Biol 22:952-964

Fischer J, Erikstein K, D'Offay B, Guggisberg S, Barone M (2012) Review of the implementation of the International Plan of Action for the Conservation and Management of Sharks. FAO, Rome

Francis M, Clarke SC, Griggs L, Hoyle SD (2014) Indicator based analysis of the status of New Zealand blue, mako and porbeagle sharks. New Zealand fisheries assessment report 2014/69. Ministry for Primary Industries, Wellington

Gallagher AJ, Orbesen ES, Hammerschlag N, Serafy JE (2014) Vulnerability of oceanic sharks as pelagic longline bycatch. Glob Ecol Conserv 1:50-59

Gilman E, Clarke S, Brothers N, Alfaro-Shigueto J and others (2007) Shark depredation and unwanted bycatch in pelagic longline fisheries: industry practices and attitudes, and shark avoidance strategies. Western Pacific Regional Fishery Management Council, Honolulu, HI
Gonzalez-Pestana A, Kouri JC, Velez-Zuazo X (2014) Shark fisheries in the Southeast Pacific: a 61-year analysis from Peru. F1000 Res 3:164

Hanson KC, Arrosa S, Hasler CT, Philipp DP, Niezgoda G, Cooke SJ (2008) Effects of lunar cycles on the activity patterns and depth use of a temperate sport fish, the largemouth bass, Micropterus salmoides. Fish Manag Ecol 15:357-364

Hayes CG, Jiao Y, Cortés E (2009) Stock assessment of scalloped hammerheads in the western North Atlantic Ocean and Gulf of Mexico. N Am J Fish Manage 29:1406-1417

> Ireland L, Connor D (2015) oceancolor_downloader: v1.1.1.

IOC, IHO, BODC (2003) Centenary edition of the GEBCO Digital Atlas (CD-ROM). British Oceanographic Data Centre, Liverpool

Kessel ST, Chapman DD, Franks BR, Gedamke T and others (2014) Predictable temperature-regulated residency, movement and migration in a large, highly mobile marine predator (Negaprion brevirostris). Mar Ecol Prog Ser 514:175-190

Lazaridis E (2014) lunar: Lunar phase \& distance, seasons and other environmental factors (Version 0.1-04). http:// statistics.lazaridis.eu (accessed 20 Jan 2016)

Litvinov FF (2006) On the role of dense aggregations of males and juveniles in the functional structure of the range of the blue shark Prionace glauca. J Ichthyol 46: 613-624

Love JW, Newhard JJ, Greenfield B (2015) A geospatial approach for estimating suitable habitat and population size of the invasive northern snakehead. J Fish Wildl Manag 6:145-157

Lowry M, Williams D, Metti Y (2007) Lunar landingsrelationship between lunar phase and catch rates for an Australian gamefish-tournament fishery. Fish Res 88: $15-23$

- Marra G, Wood SN (2011) Practical variable selection for generalized additive models. Comput Stat Data Anal 55: 2372-2387

Metcalfe NB, Valdimarsson SK, Fraser NHC (1997) Habitat profitability and choice in a sit-and-wait predator: juvenile salmon prefer slower currents on darker nights. J Anim Ecol 66:866-875

Mitchell JD, Collins KJ, Miller PI, Suberg LA (2014) Quantifying the impact of environmental variables upon catch per unit effort of the blue shark Prionace glauca in the western English Channel. J Fish Biol 85:657-670

Myers RA, Baum JK, Shepherd TD, Powers SP, Peterson CH (2007) Cascading effects of the loss of apex predatory sharks from a coastal ocean. Science 315:1846-1850

Niquen M, Bouchon M (2004) Impact of El Niño events on pelagic fisheries in Peruvian waters. Deep Sea Res II 51: 563-574

> Papastamatiou YP, Watanabe YY, Bradley D, Dee LE, Weng K, Lowe CG, Caselle JE (2015) Drivers of daily routines in an ectothermic marine predator: hunt warm, rest warmer? PLoS ONE 10:e0127807

Poisson F, Gaertner JC, Taquet M, Durbec JP, Bigelow K (2010) Effects of lunar cycle and fishing operations on longline-caught pelagic fish: fishing performance, capture time, and survival of fish. Fish Bull 108:268-281

QGIS Development Team (2015) QGIS Geographic Information System. Open Source Geospatial Foundation Project. www.qgis.org

Queiroz N, Humphries NE, Mucientes G, Hammerschlag N and others (2016) Ocean-wide tracking of pelagic sharks 
reveals extent of overlap with longline fishing hotspots. Proc Natl Acad Sci USA 113:1582-1587

Quiñones J, Mianzan H, Purca S, Robinson KL, Adams GD, Marcelo Acha E (2015) Climate-driven population size fluctuations of jellyfish (Chrysaora plocamia) off Peru. Mar Biol 162:2339-2350

R Core Team (2015) R: a language and environment for statistical computing. R Foundation for Statistical Computing, Vienna. www.r-project.org (accessed 15 July 2015)

Rice J, Harley S, Kai M (2014) Stock assessment of blue shark in the North Pacific Ocean using stock synthesis. WCPFC-SC10-2014/ SA-WP-08. Western Pacific Regional Fishery Management Council, Majuro, Marshall Islands

Robbins WD, Hisano M, Connolly SR, Choat JH (2006) Ongoing collapse of coral-reef shark populations. Curr Biol 16:2314-2319

Robinson KL, Graham WM (2013) Long-term change in the abundances of northern Gulf of Mexico scyphomedusae Chrysaora sp. and Aurelia spp. with links to climate variability. Limnol Oceanogr 58:235-253

Salas S, Chuenpagdee R, Seijo JC, Charles A (2007) Challenges in the assessment and management of small-scale fisheries in Latin America and the Caribbean. Fish Res 87:5-16

Schabetsberger R, Økland F, Aarestrup K, Kalfatak D and others (2013) Oceanic migration behaviour of tropical Pacific eels from Vanuatu. Mar Ecol Prog Ser 475: $177-190$

Schabetsberger R, Økland F, Kalfatak D, Sichrowsky U and others (2015) Genetic and migratory evidence for sympatric spawning of tropical Pacific eels from Vanuatu. Mar Ecol Prog Ser 521:171-187

Shester GG, Micheli F (2011) Conservation challenges for small-scale fisheries: bycatch and habitat impacts of traps and gillnets. Biol Conserv 144:1673-1681

Stehfest KM, Patterson TA, Barnett A, Semmens JM (2014) Intraspecific differences in movement, dive behavior and vertical habitat preferences of a key marine apex predator. Mar Ecol Prog Ser 495:249-262

Stevens J (2009) Prionace glauca. The IUCN Red List of Threatened Species 2009:e.T39381A10222811. http://dx.
doi.org/10.2305/IUCN.UK.2009-2.RLTS.T39381A10222811. en (accessed 10 Aug 2015)

Stevens J, Bonfil R, Dulvy NK, Walker P (2000) The effects of fishing on sharks, rays, and chimaeras (chondrichthyans), and the implications for marine ecosystems. ICES J Mar Sci 57:476-494

Su NJ, Sun CL, Punt AE, Yeh SZ, Dinardo G (2011) Modelling the impacts of environmental variation on the distribution of blue marlin, Makaira nigricans, in the Pacific Ocean. ICES J Mar Sci 68:1072-1080

Vandeperre F, Aires-da-Silva A, Santos M, Ferreira R, Bolten AB, Serrao Santos R, Afonso P (2014) Demography and ecology of blue shark (Prionace glauca) in the central North Atlantic. Fish Res 153:89-102

- Velez-Zuazo X, Alfaro-Shigueto J, Mangel J, Papa R, Agnarsson I (2015) What barcode sequencing reveals about the shark fishery in Peru. Fish Res 161:34-41

Walsh WA, Kleiber P (2001) Generalized additive model and regression tree analyses of blue shark (Prionace glauca) catch rates by the Hawaii-based commercial longline fishery. Fish Res 53:115-131

Williams R, Okey TA, Wallace SS, Gallucci VF (2010) Shark aggregation in coastal waters of British Columbia. Mar Ecol Prog Ser 414:249-256

Wolff M, Taylor M, Mendo J, Yamashiro C (2007) A catch forecast model for the Peruvian scallop (Argopecten purpuratus) based on estimators of spawning stock and settlement rate. Ecol Model 209:333-341

Wolter K, Timlin MS (2011) El Niño/Southern Oscillation behaviour since 1871 as diagnosed in an extended multivariate ENSO index (MEI.ext). Int $\mathrm{J}$ Climatol 31: 1074-1087

Wood SN (2006) Generalized additive models: an introduction with R, 1st edn. Chapman \& Hall/CRC, Boca Raton, FL

Wood SN, Scheipl F (2014) gamm4: Generalized additive mixed models using mgcv and lme4. http://CRAN.Rproject.org/package=gamm4 (accessed 14 Jan 2016)

Worm B, Davis B, Kettemer L, Ward-Paige CA and others (2013) Global catches, exploitation rates, and rebuilding options for sharks. Mar Policy 40:194-204 
a) P. glauca

Appendix

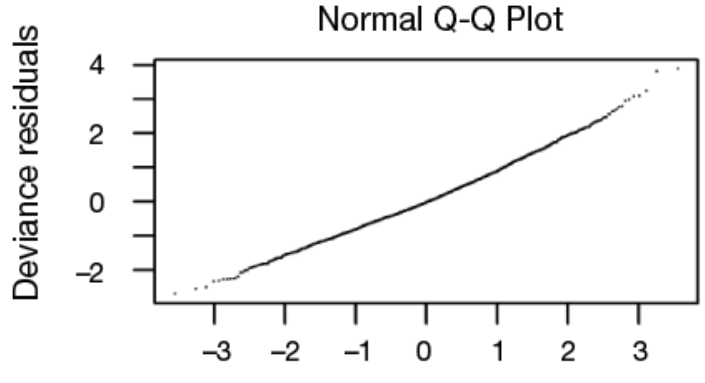

Theoretical quantiles

Histogram of residuals

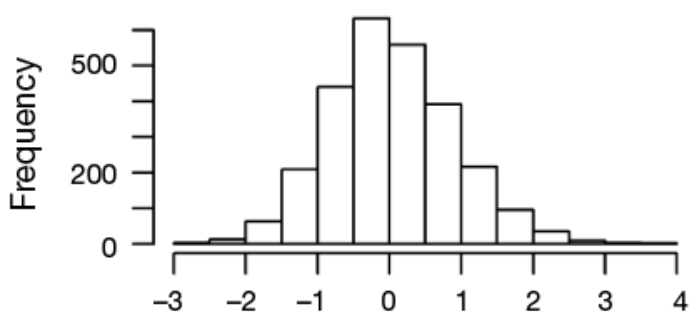

Residuals

b) I. oxyrinchus

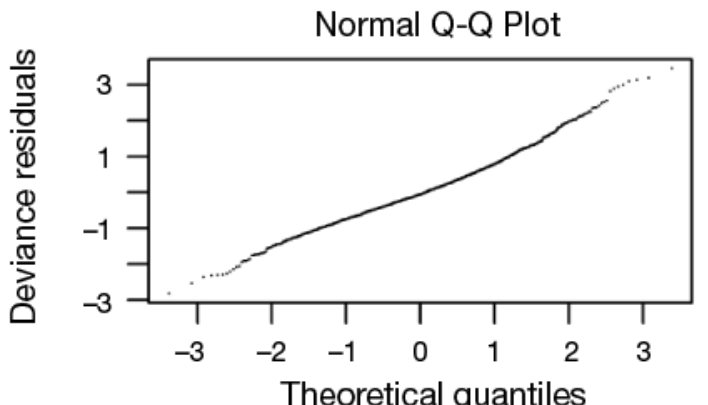

Histogram of residuals

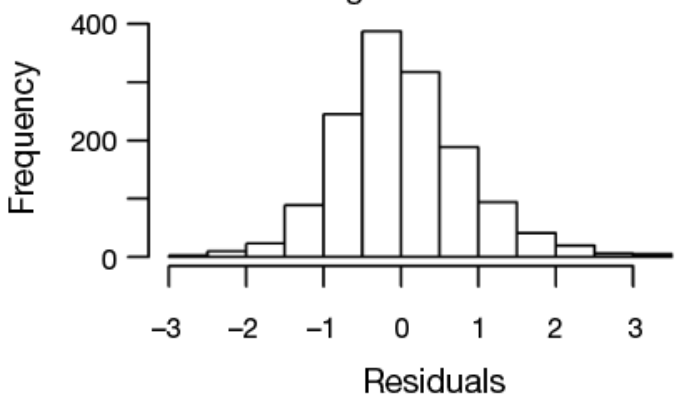

Resids vs. linear pred.

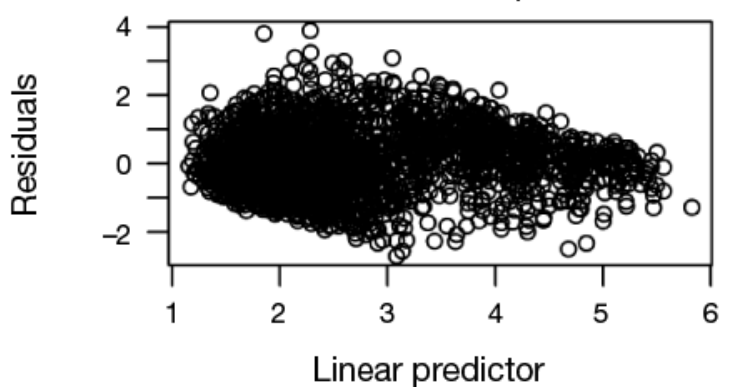

Resids vs. fitted values

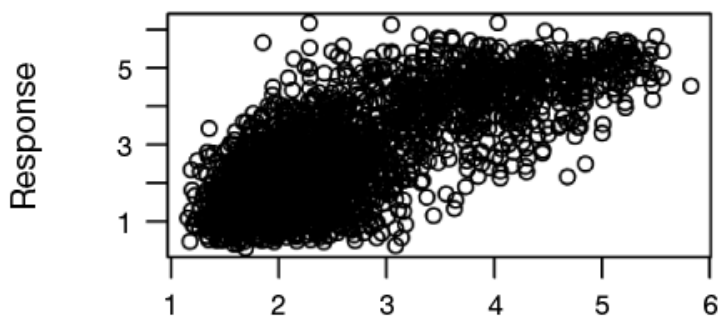

Fitted values

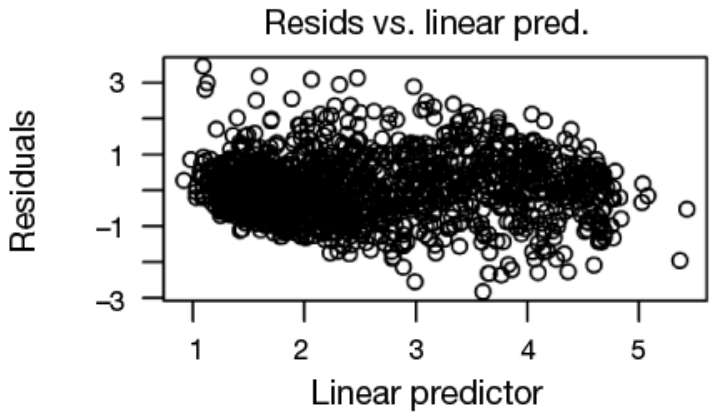

Resids vs. fitted values

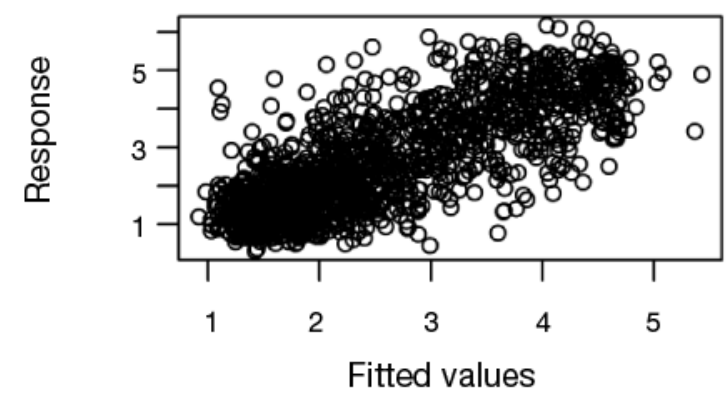

Fig. A1. Standard model diagnostics of generalized additive mixed models (GAMMs), relating (a) blue shark Prionace glauca and (b) shortfin mako shark Isurus oxyrinchus catch per unit effort $\left(\mathrm{kg} \mathrm{d}^{-1}\right)$ data to spatial-temporal and environmental variables in southern Peru

Editorial responsibility: Eric Gilman, Honululu, Hawaii, USA
Submitted: February 22, 2016; Accepted: June 2, 2016

Proofs received from author(s): August 8, 2016 